\title{
Mechanical -strength characteristics of concrete made with stainless steel industry wastes as binders
}

\author{
M. D. Rubio-Cintas¹, S. J. Barnett ${ }^{3}$, F., Perez-García², M. E. Parron-Rubio, \\ 1 Dpto. de Ingeniería Industrial y Civil, Universidad de Cádiz, 11202 Algeciras (Spain). \\ 2 Dpto. de Ingeniería Civil, Materiales y Fabricación, Universidad de Málaga, 29071 Málaga (Spain) \\ School of Civil Engineering and Surveying, University of Portsmouth (United Kingdom) \\ * Correspondence: mariadolores.rubio@uca.es
}

\begin{abstract}
One of the problems of steelworks, referring to the steel manufacture, is the generation of secondary products, resulting in recent years in new types of industrial waste that, depending on the sustainability of the environment, must be reused or treated. This paper analyzes the mechanical behaviour of concrete samples with the addition of an industrial waste, such as ferritic fume dust produced by electric arc furnaces (EAF) when the materials are melted and makes a comparison using other types of additions of concrete such us silica fume. At the same time this paper studies the capacity of the matrix to encapsulate this residue that eventually ends up deposited in a landfill. The results show that, besides giving the concrete a greater resistance as it happens with silica fume, the use of this type of waste as an addition to concrete is suitable since the material remains encapsulated in the concrete matrix, thus not producing leaching of heavy metals which can be harmful to the environment and therefore to the health of the human being.
\end{abstract}

Keywords: Concrete, Fume dust EAF, Compressive strength, Flexural strength

\section{Introduction}

One of the biggest problems today in the steel industry is the production of waste in varying amounts depending on the type of scrap used and steel to be processed, generating various types of steel including ferritic steel. Ferritic steel is a type of steel that is composed of less than $0.10 \%$ carbon. This grade of steel was developed as a stainless steel group (ACERINOX) that can resist oxidation and corrosion, specifically stress cracking corrosion (SCC). We will focus on the study of ferritic steel for our study. These materials produce large amounts of waste that build up fume dust. Said dust is generated in the combustion of the scrap inside the electric arc furnace (EAF). The powder evaporates and is extracted, then deposited in baghouse dust collectors for its later removal and deposition into landfill. These are expensive to recycle or reuse and difficult to transform into an inert waste.

Current steel production is about 1597 million tonnes according to International Iron and Steel Institute (IISI) Conferences 2015 [1]. EAF fume dust is generated in appreciable quantities when casting steel. 
37 This transformation creates environmental problems in the steel industry. Today the reuse of waste in 38 the metallurgical industry does not exist or is inappropriate.

39 From an environmental point of view, the American Environment Agency (EPA) [2,3] classified these materials as toxic and dangerous products, just as they are under Spanish legislation. The toxicity of these materials is based on their content of non-ferrous metals, mainly, chromium, zinc, lead, nickel and magnesium, all of them easily leachable metals with consequently harm caused to soil and groundwater when stored in landfills.

The high content of these components requires us to seek solutions aside from treatment and/or hazardous landfill. Furthermore, the economic importance of the recovery of certain metals (zinc...) would be significant since the waste generated in the steel manufacture is composed of a large amount of metals that can be recovered through certain processes that sometimes are cheaper than the acquisition as raw material. Recovery rates of around $2 \%$ of the gross production have been verified in the steel industry $[4,5]$.

One solution is to incorporate the steelmaking waste in concrete, either completely or partially recovered and after conducting the appropriate tests, verify the correct behaviour in the different stresses to which the new material will be exposed. Different proportions of addition were studied.

Given its characteristics fume dust has binding properties if incorporated into appropriate systems so that its reuse does not contaminate and exert a favourable effect on the system.

The results of the trials demonstrate out below improving the mechanical strength of the material.

One of the problems that industrial wastes can pose is when the solid materials come into contact with a liquid,[2,6,7] some of its components can dissolve to a lesser or greater extent, being of interest the degree of dissolution for each individual constituent. The leaching of materials can occur in the place where it is applied, by natural infiltration of water, rain, exposure to seawater, etc.

The problem of environmental pollution can be established in several branches, waste water and waste management are usually solved by solidification-stabilization [8-10].

Another of the materials used as addition and stabilization of materials is the slag electric arc furnace in which the material acquires great importance in the recovery of waste [11-15].

There are several solidification-stabilization techniques, such as: the absorption of materials, which commonly coagulate and precipitate to subsequently pass the solid phases or use cement to generate concrete blocks containing this organic waste. There are authors who have used this procedure with toxic waste from metals[16,17], or waste from the steel industry Norma UNE 83491 EX. a low technical requirement in personnel, low production cost, long-term structural stability of the concrete, high resistance to biodegradation, low permeability of concrete. 
There are a large number of factors that influence the relationship in which the constituents of a material are dissolved from the matrix material. These factors can be divided into physical and chemical.

Currently there are several legislations in the European regulations in which are found IV.39/9 34 2000/532/CE, by which a list of hazardous waste is established.

According to Spanish regulations, those listed in Annex 2 of Royal Decree 952/1997, of June 20, where the list of hazardous waste approved by Decision 94/904 / EC, of the council, of 22 December, in accordance with section 4 of article 1 of directive 91/689 / EEC

The treatments can be classified as:

- Stabilization: Treatment of the waste with chemical agents, such as lime or phosphoric acid, to reduce the mobility of the components.

- Solidification: Confine in a matrix of low permeability. This improves the mechanical properties and decreases the contact surface of the waste with the possible leachant.

- Chemical extraction: Treatment that involves washing the metals contained in the ashes with different liquids.

This type of treatment is focused on the immobilization of metals, since organic molecules are not easily incorporated into crystalline structures and it is more difficult for them to form insoluble precipitates. Stabilization and solidification processes are widely used in the management of hazardous waste.

When the waste has been treated, the efficiency of the treatment process must be evaluated, analyzing the untreated and treated waste by chemical analysis, or the so-called leachate tests, which consist of putting the sample in contact with a "leaching" agent during a certain period of time. In this way, the total content of the waste can be compared with that of the treated matrix and what is actually released in contact with the leachant. Let's see what materials make up the study.

\section{Materials}

In this section, the materials used for the development of the experiment are analyzed, these being the following.

\subsection{Ferritic Fume Dust (FFD).}

Most of our steel industry uses collection and purification systems. The collection system is mainly used in the aspiration through a fourth hole in the roof of the furnace, and subsequent uptake by extractor bells installed in various parts of the mill, mainly above the ovens. The gases captured by the hood are conducted through channels to the fourth filter or bag filters. Emissions generated in the AOD converter (Decarburization converter with Oxygen and Argon) are also captured and directed to the channel and filtered together with the gases of the electric furnace. 
Thus the solid obtained is a very fine dust material with between 15 and $25 \mathrm{~kg}$ of dust produced per ton of steel.

Morphologically,[18-20] electric arc furnace (EAF) fume dust consists of spheroidal particles of highly variable diameters (Figures 1 and 2), ranging from 50 to 500 microns. Its moisture content is below $1 \%$ by weight. The wide distribution of particle sizes is due to both the composition and origin of the raw materials, as well as differences in the production process. As shown in Figure 1, EAF fume dust, despite being an industrial waste, it has the potential to modify the gel structure, and fill the gaps between the grains of cement and various aggregates increasing hydration of the cement and reducing the capillary void volume of the concrete[21].

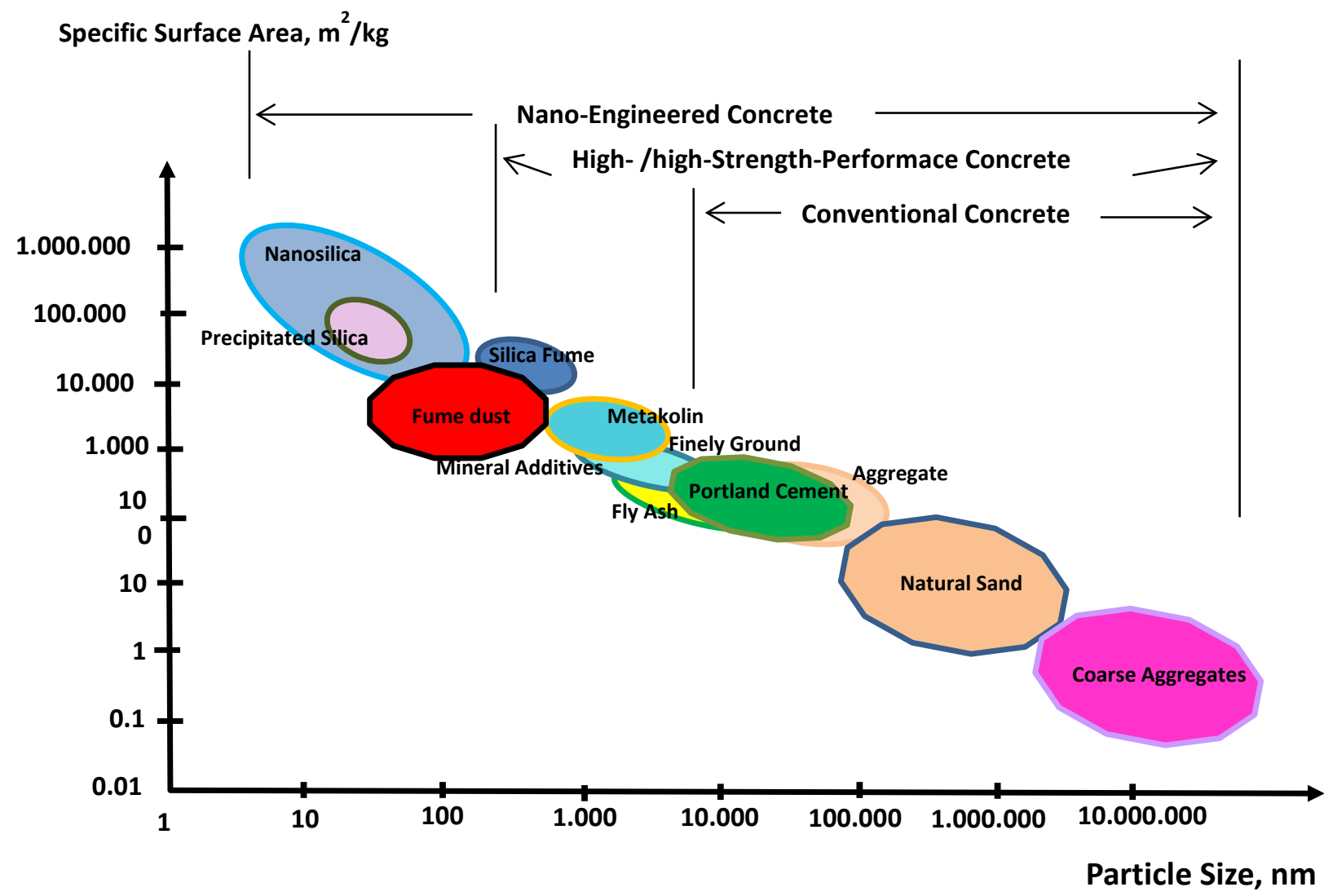

Figure 1. Scale of different types of components

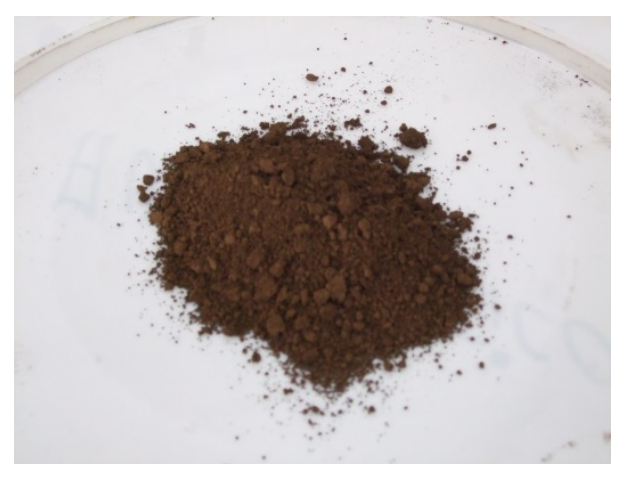

Figure 2. Ferritic fume dust 
The sample used in this study was obtained from a random fraction contained in the bag filters where the waste is stored. From each of these samples approximately $50 \mathrm{~kg}$ were taken, always preserved in closed containers to prevent the action of moisture. Then, $250 \mathrm{~g}$ of both samples were taken to proceed to perform a granulometric study[22].

Figure 3 shows the results obtained where the amount of material that does not cross the corresponding sieve are collected. It is noted that the majority of material is in the range 53-297 microns.

163

164

165

166

167

168

169

170

171

172

173

174

175

176

177

178

179

180

181

182

183

184

185

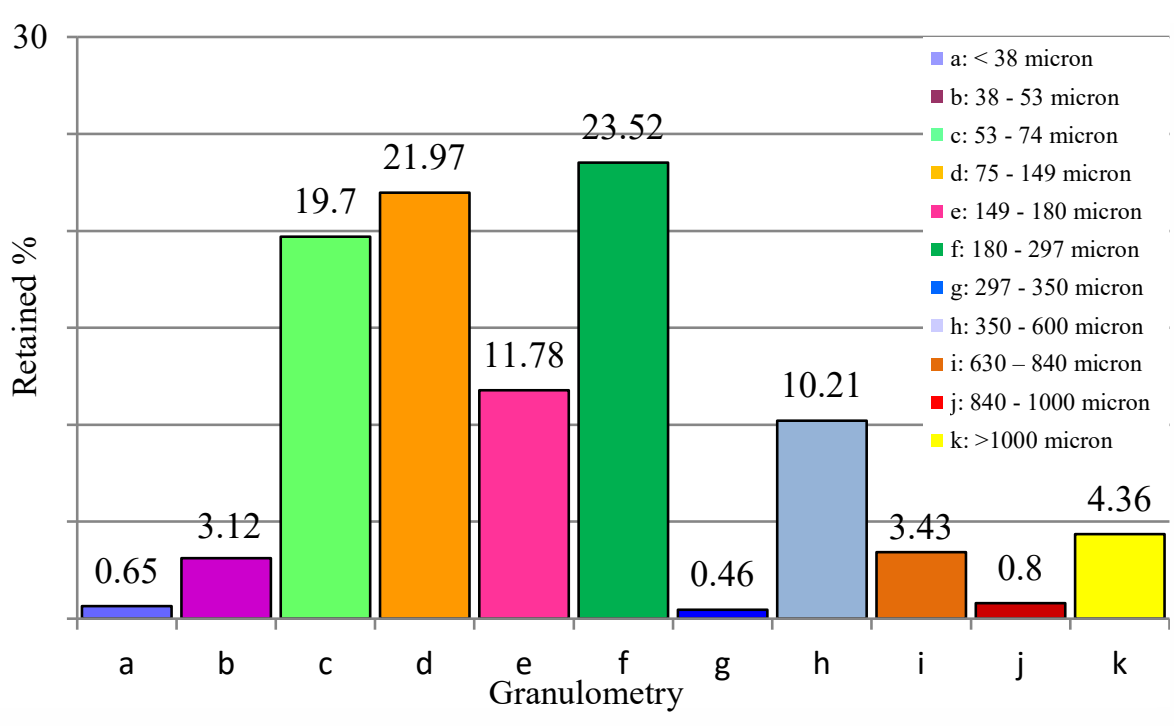

Figure 3 Ferritic fume dust granulometry

The $77.06 \%$ of the grains are within this range. The particle size distribution is not symmetrically shaped but right correspond one $19.17 \%$ and to the left a $3.77 \%$ of the material analysed[23-25].

For the determination of the chemical and mineralogical composition of the EAF fume dust, X-ray fluorescence, X-ray diffraction (XRD) and thermogravimetric analysis (TGA) were carried out.

Table 1 shows the chemical composition obtained by XRF.

\begin{tabular}{|l|c|}
\hline $\begin{array}{l}\text { Chemical } \\
\text { elements }\end{array}$ & Content \% \\
\hline Carbon (C) & $0.20-0.50$ \\
\hline Silicon (Si) & $2.00-4.00$ \\
\hline Manganese (Mn) & $1.50-2.50$ \\
\hline Tin (Ti) & $<0.010$ \\
\hline Nickel(Ni) & $<0.30$ \\
\hline Copper $(\mathrm{Cu})$ & $0.20-0.50$ \\
\hline Chrome(Cr) & $7.00-9.00$ \\
\hline Molybdenum(Mb) & $0.10-0.20$ \\
\hline
\end{tabular}




\begin{tabular}{|l|c|}
\hline Iron $(\mathrm{Fe})$ & $23.00-32.00$ \\
\hline Calcium(Ca) & $6.50-8.00$ \\
\hline Lead $(\mathrm{Pb})$ & $1.00-1.50$ \\
\hline Zinc $(\mathrm{Zn})$ & $10.00-20.00$ \\
\hline Magnesium $(\mathrm{Mg})$ & $2.00-3.00$ \\
\hline
\end{tabular}

Table 1. Chemical composition of ferritic fume dust obtained by (XRF)

The figure 4 shows the results of thermogravimetric analysis for EAF fume dust sample.

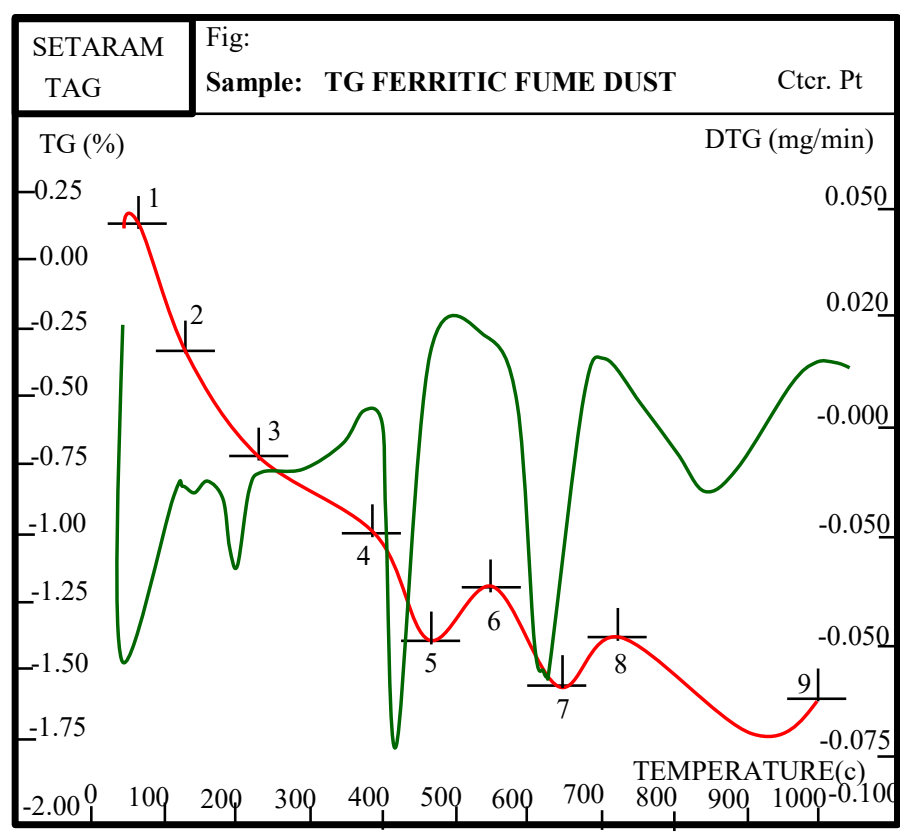

Figure 4 Thermogravimetric analysis of EAF fume dust

Figure 4 shows the thermogravimetic analysis (in red) and differential thermal analysis (shown in green). Figure 5 shows the X-ray diffraction analysis of the sample. 
253 This phenomenon repeats itself later around $600{ }^{\circ} \mathrm{C}$, and likely corresponds to a second transformation 254 of maghemite to hematite according to

$$
\gamma-\mathrm{Fe}_{2} \mathrm{O}_{3} \rightarrow \propto-\mathrm{Fe}_{2} \mathrm{O}_{3}
$$

255 Both phenomena of structural transformation (transition from one phase to another) mask losses due 256 to decomposition of carbon and calcium (about $600^{\circ} \mathrm{C}$ ) in the thermogram, seen in the second peak of 
257 the graph, which gives information from the decomposition of alkali carbonates is at temperatures 258 around $800{ }^{\circ} \mathrm{C}$.

259 The actual particle density $\left(3.76 \mathrm{~g} / \mathrm{cm}^{3}\right)$ and bulk density $\left(1.06 \mathrm{~g} / \mathrm{cm}^{3}\right)$ of the powder sample were 260 obtained using a pycnometer to subsequently make a comparison of densities in the compact.

\subsection{Ordinary Portland Cement}

The cement used as binder for every concrete mixture is an ordinary clinker Portland cement supplied by a local company and categorized as type CEM I $52.5 \mathrm{R}$ with a bulk density of $3.1 \mathrm{~g} / \mathrm{cm}^{3}$, whose main components are, calcium oxide, silicon oxide, aluminum oxide, iron oxide and magnesium oxide 267 in different proportions according to the manufacturer.

\subsection{Silica Fume}

270 Silica fume is an established material for use in high and ultra-high performance concrete. It 271 contributes to strength through filler effects as well as by pozzolanic reaction. Since it falls within a 272 similar size range to the EAF fume dust, it was used for comparative purposes. The properties of the 273 silica fume used in the study are given in Table 2.

2.4. Aggregates.

\begin{tabular}{|c|c|}
\hline Appearance & Gray powder \\
\hline Density at $20^{\circ} \mathrm{C}$ (real) & $>2.3 \mathrm{~g} / \mathrm{cm}^{3}$ \\
\hline Apparent density & Aprox. $0,2 \mathrm{~g} / \mathrm{cm}^{3}$ \\
\hline content $\mathrm{SiO}_{2}$ & $>90 \%$ \\
\hline Chloride content & $<0.1 \%$ \\
\hline
\end{tabular}

The aggregates used were crushed limestone aggregates, from commercial manufacturing plants used, according to UNE-EN 933-2. 


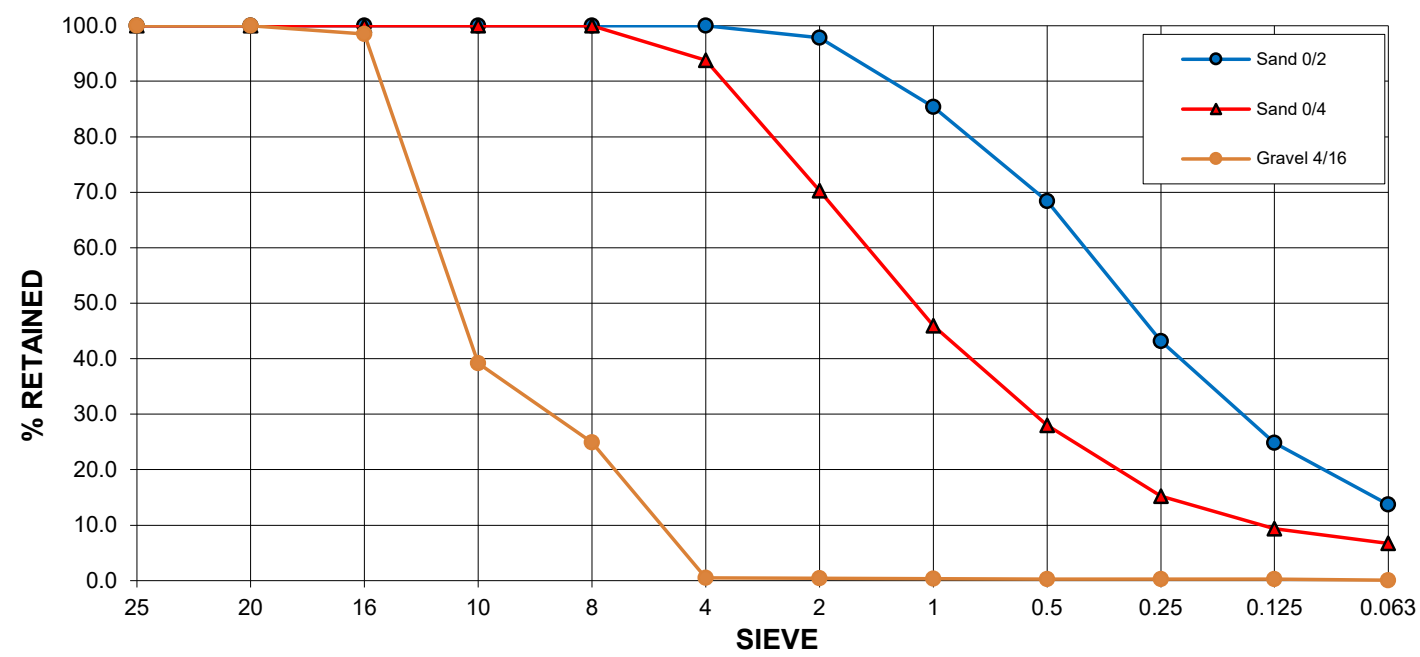

\subsection{Additive.}

In order to meet workability requirements of the concrete a superplasticizer additive was used. The additive used in all the concretes has been the Glenium ACE-324, of the commercial mark BASF.

\subsection{Water.}

Domestic tap water was used

\section{Process description}

3.1. Mixture design and manufacture.

The process for the manufacture of concrete is described below according to the different proportions or values depending on the additions. Six concrete mixtures were produced. Ferritic Fume Dust was included as an addition at levels of 5, 10 and 15\%. Two concrete mixtures containing silica fume (10 and $15 \%$ ) as well as a control mix containing only CEM I were also produced.

The nomenclature used for the concrete produced in the study is as follows:

- FFD $5=$ concrete with an addition of 5\% (spc) ferritic fume dust.

- FFD $10=$ concrete with an addition of $10 \%$ (spc) ferritic fume dust.

- FFD $15=$ concrete with an addition of $15 \%$ (spc) ferritic fume dust.

- SF $10=$ concrete with an addition of $10 \%$ (spc) silica fume.

- SF $15=$ concrete with an addition of $15 \%$ (spc) silica fume. 
- NA = conventional concrete without addition

The W/C that has been chosen, in all cases, was 0.5 as we can see in Table 3 . The addition of both

\begin{tabular}{|c|c|c|c|c|c|c|c|}
\hline \multirow[b]{2}{*}{ Mix } & \multirow[b]{2}{*}{$\begin{array}{l}\text { Water } \\
\text { (w/c } \\
\text { ratio) }\end{array}$} & \multicolumn{2}{|c|}{ Binder } & \multirow[b]{2}{*}{$\begin{array}{l}\text { Additive } \\
\%\end{array}$} & \multicolumn{3}{|c|}{ Aggregates } \\
\hline & & $\begin{array}{c}\text { Cement Dosage } \\
\mathrm{Kg} / \mathrm{m}^{3}\end{array}$ & $\begin{array}{c}\text { Addition } \\
\%\end{array}$ & & $\begin{array}{l}\text { Dosage } \\
\mathrm{Kg} / \mathrm{m}^{3}\end{array}$ & $\begin{array}{c}\text { Sand } 0-4 \\
\quad \%\end{array}$ & $\begin{array}{l}\text { Gravel } \\
4-16 \%\end{array}$ \\
\hline NA & & & $0 \%$ & & & & \\
\hline FFD 5 & & & $5 \%$ of FFD & & & & \\
\hline FFD 10 & 0.5 & $325 \mathrm{Kg} / \mathrm{m}^{3}$ & $10 \%$ of FFD & $1.2 \%$ & $2033.8 \mathrm{~kg} / \mathrm{m}^{3}$ & $50 \%$ & $50 \%$ \\
\hline FFD 15 & 0.3 & & $15 \%$ of FFD & & & & \\
\hline SF 10 & & & $10 \%$ of SF & & & & \\
\hline SF 15 & & & $15 \%$ of $S F$ & & & & \\
\hline
\end{tabular}

Table 3. Concrete mixture proportion.

These concretes were manufactured in a mixer with rotating vertical axis and fixed blades, with a capacity of 80 litres. A soft consistency of 7.1 was obtained according to the UNE-EN 12350-2 standard.

Once mixed the concretes were poured into die and vibrated for compaction, using a vibrating table at a frequency of $42 \mathrm{~Hz}$ (2400 cycles per minute) according to UNE 12390-2[26].

Specimens were covered with plastic for 24 hours and then were demoulded and brought into a moist chamber for curing at a relative humidity not less than $95 \%$ and a temperature of $20 \pm 2^{\circ} \mathrm{C}$. Finally the samples were extruded according to norm UNE-EN 12390-4.

These specimens were kept in the chamber until use, 24 hours before testing.

\subsection{Compression strength tests.}

Compression testing was performed according to standard UNE-EN 12390-3 [27]:

The geometry of the test pieces for compression tests were cylindrical according to standard dimensions of diameter $d$ and height $2 d$. In our case their dimensions correspond with $45 \mathrm{~mm}$ diameter and $90 \mathrm{~mm}$ height as shown in Figure 7. According to UNE-EN 12504-1 standard if the thick aggregate does not exceed $20 \mathrm{~mm}$ in diameter. Cylindrical specimens were cut without alteration of mortar and coarse aggregate. As the surface was flat, the facing of the test surfaces was dispensed with.
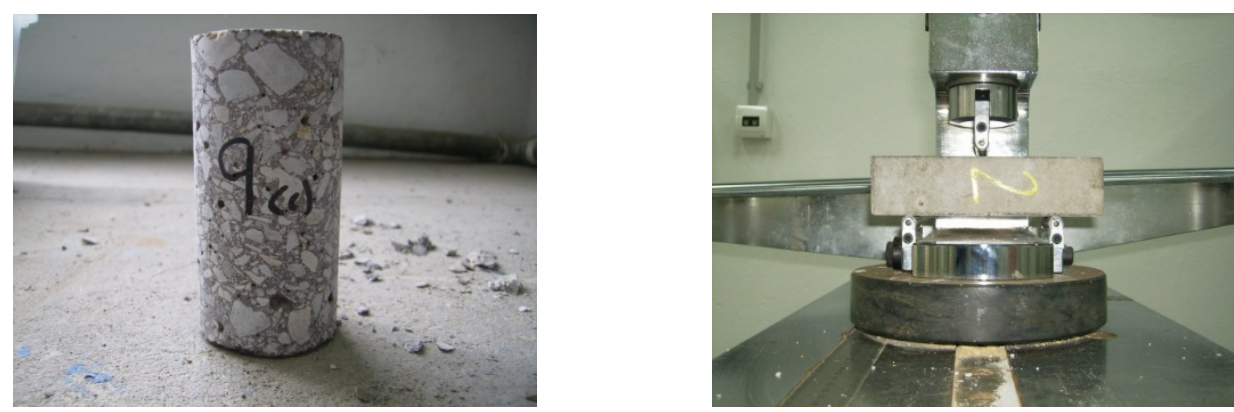
348 For performing compression tests, three replicate specimens for each concrete mix were tested at ages 349 of 7, 28 and 90 days.

350

\subsection{Flexural strength tests.}

The flexural test samples with the same characteristics were performed using prismatic specimens with dimensions according to regulations square section edge $d$ and length $2 d$ or $4 d$, in our case the dimensions of these specimens are $40 \times 40 \times 160 \mathrm{~mm}$ as shown in Figure 8, according to UNE 123901 standard, provided that $\mathrm{L} \geq 3.5 \mathrm{~d}$ in this case $3.5 \times 16=56 \mathrm{~mm}$.

Following the flexural test, the two halves originating from the failed specimen were tested in compression. As the section is square, one can obtain a modified or equivalent cube load applied by square plates with the same dimensions as the cross section of the prism.

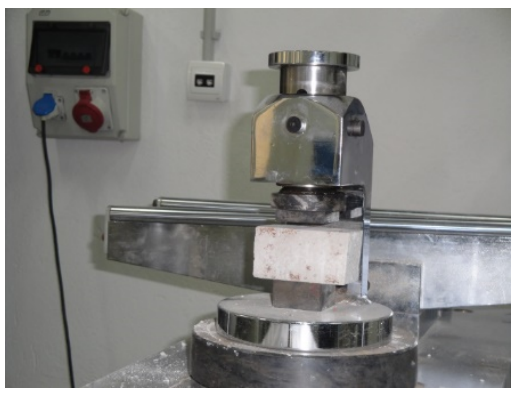

Figure 8. Charging device cubic specimens for compressive

According to Neville $[5,14,17,28]$ the resistance of the modified specimen, would be $5 \%$ higher than the normal cube specimen of the same size, because of the lateral containment due to excesses in relation to the hub. In this study an average relationship is obtained, since the test was performed using 2 for each of the specimens tested for flexural strength. Said test is carried out as a comparative of the previous one.

\subsection{Leaching test.}

The study was developed based on the UNE-EN 12920 standard. The different processes and steps to be followed have been applied according to this regulation.

This standard provides a methodology to determine the leaching behavior of a waste under specific conditions, that is, in a solidification / stabilization scenario within a specific time frame, in our case corresponding to 100 years. A selection of tests is required depending on the problem and the scenario to be evaluated $[29,30]$.

This methodology is specific to determine a leachate behavior of a waste under specific conditions, since the stabilization / solidification of the material is used. Therefore, external conditions that have an influence on the release of components of the waste in question were considered. 
It is intended to see if said matrix is capable of retaining the heavy metals within it without any deterioration in the material being produced, under accelerated conditions and subsequently the determination of the leaching behavior within the specified time frame.

To determine the behavior in the material, two different tests were carried out, - The first was to study specimens of $45 \mathrm{~mm}$ in diameter and $90 \mathrm{~mm}$ in height, with an addition of $15 \%$ FFD, this being the highest amount of fume dust considered in this research. These were cured for 28 days in wet camera to see the proportions of heavy materials that gave off in this first leaching.

The test sample was immersed in $800 \mathrm{ml}$ of distilled water for 24 hours. After the test period, the sample was extracted and the leachate solution was transferred to a $1000 \mathrm{~mL}$ volumetric flask and made up to the mark with distilled water. The test was repeated by immersing the test sample for 24 hours more in another $800 \mathrm{~mL}$ of water, repeating the described methodology.

- In the second test, the specimens were aged rapidly. After 28 days of curing in a humid chamber, test samples were subjected to oven drying at $60^{\circ} \mathrm{Cfor} 48$ hours and then immersed in a water bath at $70 \mathrm{C}$ for another 32 days. Then they were deposited on the street exposed to the elements for 3 months. Once aged, the same technique described in the previous paragraph for the leaching test was developed.

\section{Results and discussion}

\subsection{Flexural and compressive strength}

In Table 4 the results of tests with cylindrical specimens are detailed. The table shows the average values obtained after breaking three specimens in each case, being the evaluation of rupture mode, according to regulations, satisfactory.

\begin{tabular}{|c|c|c|c|}
\hline Mix description & $\begin{array}{c}7 \text { days } \\
(\mathrm{MPa})\end{array}$ & $\begin{array}{c}28 \text { days } \\
(\mathrm{MPa})\end{array}$ & $\begin{array}{c}90 \text { days } \\
(\mathrm{MPa})\end{array}$ \\
\hline FFD 5 & 38.3 & 41.7 & 45.3 \\
\hline FFD 10 & 41.3 & 40.2 & 54.8 \\
\hline FFD 15 & 50.6 & 51.6 & 61.8 \\
\hline SF 10 & 43.1 & 46.2 & 59.5 \\
\hline SF 15 & 38.3 & 42.2 & 52.5 \\
\hline NA & 37.3 & 39.1 & 51.3 \\
\hline
\end{tabular}


420 Following the flexural test, the two halves originating from the tested specimen were tested in 421 compression. Results of flexural strength test at 28 days and compressive strength at 40 days are shown 422 in Table 5 and Table 6 respectively.

\begin{tabular}{|c|c|}
\hline Sample & 28 days (MPa) \\
\hline FFD 5 & 13.9 \\
\hline FFD 10 & 12.6 \\
\hline FFD 15 & 11.1 \\
\hline SF 10 & 11.9 \\
\hline SF 15 & 11.1 \\
\hline NA & 8.65 \\
\hline
\end{tabular}

Table 5 Results of prismatic specimens, flexural tests.

\begin{tabular}{|c|c|}
\hline Mixed description(\%) & $\begin{array}{c}\text { Break to 40 days } \\
\text { (MPa) }\end{array}$ \\
\hline FFD 5 & 55.71 \\
\hline FFD 10 & 54.80 \\
\hline FFD 15 & 70.25 \\
\hline SF 10 & 69.87 \\
\hline SF 15 & 57.54 \\
\hline NA & 57.44 \\
\hline
\end{tabular}

Table 6. Results of cubic specimens. Compression tests.

432 In various tests, particularly for cylindrical samples, compressive strength increased with increasing 433 amount of powder of ferritic fume dust in the concrete composition, while the addition of silica fume 434 decreases effect and Kadri referenced by Duval[31,32] . 


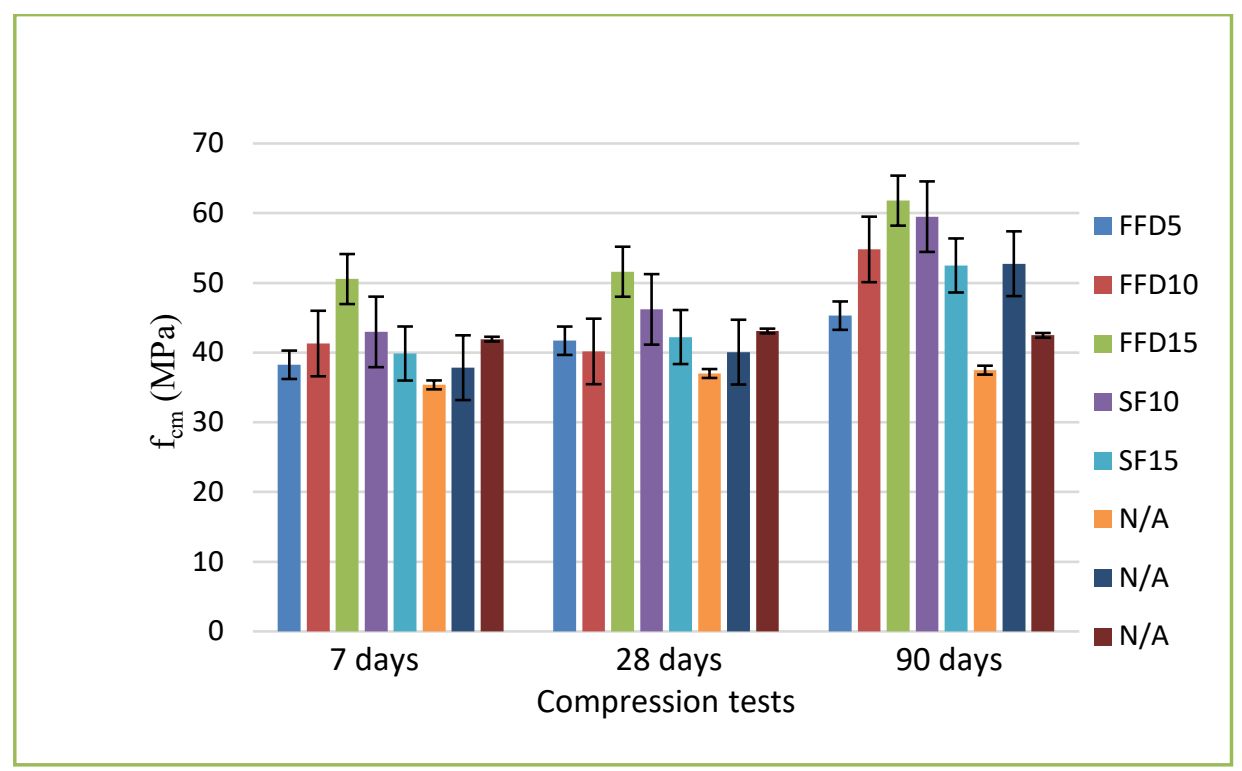

Figure 9. Compressive strength on cylindrical specimens (error bars indicate the standard deviation).

To 7 days appreciate that increasing the strength of the material begins to be significant primarily with the addition of $15 \%$ fume dust as surpasses even high strength concrete made adding silica fume.

At 28 days the increase is quite relevant, compared to the rest, when the addition is $15 \%$ ferritic fume dust.

90 days note that unlike what happens with silica fume powder, the higher the addition of powdered ferritic fume dust, compression strength of the material increases, reaching a difference of $9.3 \mathrm{MPa}$ with respect SF15\% of more than $15 \%$ increase, although with FFD $10 \%$ is $2,3 \mathrm{MPa}$ only slightly less than $5 \%$ increase. Draw attention to the strong improvement produced with the addition of fume dust respect to silica fume.

If the FFD15\% compared with conventional concrete gain it is $10.5 \mathrm{MPa}$, up from $15 \%$ the difference with NA.

The results show that concrete with 15\% ferritic fume dust (FFD15) acquire a higher resistance again in respect of comparative equivalent performed for cylindrical specimens for both concretes with added silica fume $15 \%$ and $10 \%$ and conventional concrete. That is, FFD 15 increased by $2 \%$ over the SF10, up $18 \%$ compared to SF10 equal increment on concrete NA.

Contrary to the results obtained for compression, and as shown in Table 6 , in the case of the flexural strength, are higher values as decreases powder addition ferritic fume dust, jumping almost $14 \mathrm{MPa}$ of FFD5 the value of $11 \mathrm{MPa}$ for the addition FFD15. This is a loss of about $25 \%$ of the addition as we increase resistance of ferritic fume dust. This fact must be taken into account as previously exhibited levels of fissuring obtained by the addition, resulting in a positive development since the flexural strength obtained by adding PHF15 is similar to that obtained for concrete with addition powder silica fume, then the levels of cracking in the absence of a formal verification is not the subject of this work, will be equivalent.

If we make a comparison with conventional concrete, increased flexural strength is notable for each addition FFD15, FFD10 and FFD5 rising from just over 25\% higher than Portland cement concrete to 
almost $60 \%$, respectively. This data supports the idea of the decrease in cracking of concrete with added ferritic fume dust.

467 In Figure 10 the bar chart with this line down on resistance just discussed is located.

\subsection{Leaching analysis}

Figure 10. Flexural strength of concrete (error bars indicate the standard deviation).

Tables 7,8 and 9 show the results corresponding to the total content of heavy and non-heavy metals.

The results are shown in parts per million (ppm). In the different tables a comparison is made between 482

FFD and SF has a similar behaviour as nano particles that fill the voids of the cement matrix [21,33]. For this reason, an improvement of the mechanical characteristics of the concrete mixtures studied in this work has been observed. the simply cured and aged samples. The weights of the test pieces are taken in grams for the approximation in $\mathrm{mg} / \mathrm{kg}$ of dry matter.

\begin{tabular}{|c|c|c|c|c|c|c|}
\hline \multicolumn{3}{|c|}{$\begin{array}{l}\text { Components } \\
\text { Test tubes }\end{array}$} & \multicolumn{2}{|c|}{ Ferritic fume dust (FFD 5\%) } & \multicolumn{2}{|c|}{ Conventional concrete } \\
\hline \multicolumn{3}{|c|}{ Mass Test tubes g } & \multicolumn{2}{|c|}{365.95} & \multicolumn{2}{|c|}{353,00} \\
\hline \multicolumn{3}{|c|}{ Leaching } & $\begin{array}{c}1 \text { st } \\
\text { Non-aged } \\
\text { leaching }\end{array}$ & $\begin{array}{c}\text { 2nd } \\
\text { Non-aged } \\
\text { leaching }\end{array}$ & $\begin{array}{c}1 \text { st } \\
\text { Non-aged } \\
\text { leaching }\end{array}$ & $\begin{array}{c}\text { 2nd } \\
\text { Non-aged } \\
\text { leaching }\end{array}$ \\
\hline \multirow{5}{*}{ 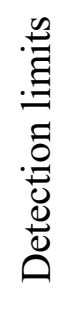 } & 0.1 & $\mathrm{Ca}$ & 1.59 & 0.9 & 1.56 & 1.76 \\
\hline & 0.004 & $\mathrm{Cr}_{\text {Total }}$ & 0.045 & 0.057 & 0.007 & 0.023 \\
\hline & 0.042 & $\mathrm{Fe}$ & 0.062 & $<\mathrm{LD}$ & $<\mathrm{LD}$ & $<\mathrm{LD}$ \\
\hline & 0.09 & $\mathrm{SO}_{4}=$ & 6.91 & 2.17 & 17.90 & 14.15 \\
\hline & 0.014 & $\mathrm{Zn}$ & 0.016 & 0.002 & 0.014 & $<\mathrm{LD}$ \\
\hline
\end{tabular}




\begin{tabular}{|c|c|c|c|c|c|}
\hline 1.9 & $\mathrm{Na}$ & 22.51 & 10.38 & 16.81 & 7.15 \\
\hline 0.001 & $\mathrm{Mn}$ & 0.001 & $<\mathrm{LD}$ & $<\mathrm{LD}$ & $<\mathrm{LD}$ \\
\hline 0.014 & $\mathrm{Al}$ & 0.095 & 0.066 & 0.071 & 0.042 \\
\hline 0.056 & $\mathrm{~K}$ & 37.27 & 18.62 & 28.15 & 17.87 \\
\hline 0.025 & $\mathrm{Si}$ & 2.18 & 1.76 & 2.75 & 1.190 \\
\hline \multicolumn{2}{|c|}{$\mathrm{TDS}(\mathrm{ppm})$} & 101 & 57.46 & 82.59 & 54.09 \\
\hline $\begin{array}{c}\text { Conductivity } \\
(\mu \mathrm{S} / \mathrm{cm})\end{array}$ & 179 & 103.5 & 147.6 & 97.6 \\
\hline \multicolumn{2}{|c|}{$\mathrm{pH}$} & 9.250 & 8.680 & 8.990 & 8.160 \\
\hline
\end{tabular}

483

Table 7 Ferritic fume dust leaching result (FFD5\%) results with conventional concrete in non-aged specimens

\begin{tabular}{|c|c|c|c|c|c|c|}
\hline \multicolumn{3}{|c|}{$\begin{array}{c}\text { Components } \\
\text { Test tubes } \\
\end{array}$} & \multicolumn{2}{|c|}{ Ferritic fume dust (FFD10) } & \multicolumn{2}{|c|}{ Conventional concrete } \\
\hline \multicolumn{3}{|c|}{ Mass Test tubes $\mathrm{g}$} & \multicolumn{2}{|c|}{365.95} & \multicolumn{2}{|c|}{353.26} \\
\hline \multicolumn{3}{|c|}{ Leaching } & $\begin{array}{c}\text { 1st } \\
\text { Non-aged } \\
\text { leaching }\end{array}$ & $\begin{array}{c}\text { 2nd } \\
\text { Non-aged } \\
\text { leaching }\end{array}$ & $\begin{array}{c}\text { st } \\
\text { Non-aged } \\
\text { leaching }\end{array}$ & $\begin{array}{c}\text { 2nd } \\
\text { Non-aged } \\
\text { leaching } \\
\end{array}$ \\
\hline \multirow{10}{*}{ 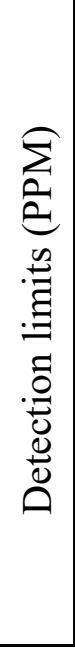 } & 0.1 & $\mathrm{Ca}$ & 1.59 & 0.95 & 1.56 & 1.76 \\
\hline & 0.004 & $\mathrm{Cr}_{\text {Total }}$ & 0.046 & 0.067 & 0.007 & 0.024 \\
\hline & 0.042 & $\mathrm{Fe}$ & 0.071 & $<\mathrm{LD}$ & $<\mathrm{LD}$ & $<\mathrm{LD}$ \\
\hline & 0.001 & $\mathrm{Mn}$ & 0.001 & $<\mathrm{LD}$ & $<\mathrm{LD}$ & $<\mathrm{LD}$ \\
\hline & 0.09 & $\mathrm{SO}_{4}$ & 10.09 & 2.78 & 17.90 & 14.15 \\
\hline & 0.002 & $\mathrm{Zn}$ & 0.014 & $<\mathrm{LD}$ & 0.014 & $<\mathrm{LD}$ \\
\hline & 1.9 & $\mathrm{Na}$ & 24.15 & 10.22 & 16.81 & 7.15 \\
\hline & 0.014 & $\mathrm{Al}$ & 0.084 & 0.066 & 0.071 & 0.042 \\
\hline & 0.056 & $\mathrm{~K}$ & 48.46 & 22.88 & 28.15 & 17.87 \\
\hline & 0.025 & $\mathrm{Si}$ & 2.48 & 1.89 & 2.75 & 1.90 \\
\hline \multicolumn{3}{|c|}{ TDS (ppm) } & 117 & 63.67 & 82.59 & 54.09 \\
\hline \multicolumn{3}{|c|}{$\begin{array}{c}\text { Conductivity } \\
(\mu \mathrm{S} / \mathrm{cm})\end{array}$} & 215 & 114.4 & 147.6 & 97.6 \\
\hline \multicolumn{3}{|c|}{$\mathrm{pH}$} & 9.3 & 8.6 & 8.990 & 8.160 \\
\hline
\end{tabular}

Table 8 Ferritic fume dust leaching result (FFD10\%) results with conventional concrete in non-aged specimens .

\begin{tabular}{|c|c|c|c|c|}
\hline $\begin{array}{c}\text { Components } \\
\text { Test tubes }\end{array}$ & \multicolumn{2}{|c|}{ Ferritic fume dust (FFD15) } & \multicolumn{2}{c|}{ Conventional concrete } \\
\hline Mass Test tubes g & \multicolumn{2}{|c|}{362.00} & \multicolumn{2}{c|}{353.26} \\
\hline Leaching & $\begin{array}{c}\text { 1st } \\
\text { Non-aged } \\
\text { leaching }\end{array}$ & $\begin{array}{c}\text { 2nd } \\
\text { Non-aged } \\
\text { leaching }\end{array}$ & $\begin{array}{c}\text { 1st } \\
\text { Non-aged } \\
\text { leaching }\end{array}$ & $\begin{array}{c}\text { Non-aged } \\
\text { leaching }\end{array}$ \\
\hline
\end{tabular}




\begin{tabular}{|c|c|c|c|c|c|c|}
\hline \multirow{8}{*}{ 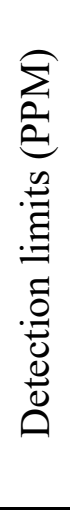 } & 0.1 & $\mathrm{Ca}$ & 1.971 & 2.603 & 1.56 & 1.76 \\
\hline & 0.004 & $\mathrm{Cr}_{\text {Total }}$ & 0.005 & $<\mathrm{LD}$ & 0.007 & 0.023 \\
\hline & 0.09 & $\mathrm{SO}_{4}$ & $<\mathrm{LD}$ & $<\mathrm{LD}$ & 17.90 & 14.15 \\
\hline & 0.002 & $\mathrm{Zn}$ & $<\mathrm{LD}$ & $<\mathrm{LD}$ & 0.014 & $<\mathrm{LD}$ \\
\hline & 1.9 & $\mathrm{Na}$ & $<\mathrm{LD}$ & $<\mathrm{LD}$ & 16.81 & 7.15 \\
\hline & 0.014 & $\mathrm{Al}$ & $<\mathrm{LD}$ & $<\mathrm{LD}$ & 0.071 & 0.042 \\
\hline & 0.056 & $\mathrm{~K}$ & 1.806 & 0.978 & 28.15 & 17.87 \\
\hline & 0.025 & $\mathrm{Si}$ & 0.228 & 0.240 & 2.75 & 1.90 \\
\hline \multicolumn{3}{|c|}{ TDS (ppm) } & 13.87 & 11.91 & 82.59 & 54.09 \\
\hline \multicolumn{3}{|c|}{$\begin{array}{c}\text { Conductivity } \\
(\mu \mathrm{S} / \mathrm{cm})\end{array}$} & 27.04 & 23.6 & 147.6 & 97.6 \\
\hline \multicolumn{3}{|c|}{$\mathrm{pH}$} & 8.61 & 8.15 & 8.99 & 8.16 \\
\hline
\end{tabular}

490

491

492

493 From the observation in Table 7 an immediate conclusion is drawn, the parameters that are found in 494 495 496 497 498 499 500 501 502 503 504 505 506 507 508 509 510 511

Table 9 Ferritic fume dust leaching result (FFD15\%) results with conventional concrete in non-aged specimens

greater abundance in the first leaching is the value of the $\mathrm{Cr}_{\text {Total }}$ although lower in the first balance due to the decrease in $\mathrm{PH}$ and the consequent partial dilution, since in the 2nd leaching it grows instead of decreasing. As expected in the second leaching, there is generally a decrease in the concentration of leached species[34,35].

Also note that in Tables 8 and 9 the amounts of total chromium in conventional concrete samples are greater than those given for concrete added with ferritic fume dust.

On page 36 of Directive [36,37] Official Journal of the European Communities DO L 11 de 16.1.2003, p. 27/48; Directive with the Council Decision of 19/12/2002 2003/33/CE on "Criterion and acceptance procedures waste in landfills". The maximum limit for total chromium is $4 \mathrm{mg} / \mathrm{Kg}$ of dry matter calculated in terms of total release, for proportions between liquid and solid (L/S) of $2 \mathrm{~L} / \mathrm{kg}$. This value is the least permissive of the set of tables that are dictated in this European Directive. If we make the balance in $\mathrm{mg} / \mathrm{kg}$ of dry matter of the total chromium of table 9 above and with an easy proportion, it is determined that in our samples the leaching is lower

$$
\frac{0,057 \mathrm{mg} \times 1000 \mathrm{~g}}{362,41 \mathrm{~g}} \Rightarrow 0,157 \frac{\mathrm{mg}}{\mathrm{kg}} \text { dry materials }
$$

Comparing it with a liter of water, if we take it to the proportion formulated in the table of $2 \mathrm{~L} / \mathrm{kg}$, this value reaches $0.315 \mathrm{mg} / \mathrm{kg}$ well below the maximum limit of $4 \mathrm{mg} / \mathrm{kg}$ imposed by the standard. 
The variability of other metal oxides is large qualitatively but quantitatively negligible, being narrower marked previously in the $\mathrm{Cr}$ representing one tenth of the assigned limit. The average of these parameters is less than $5 \%$.

In addition to the leaching limit values mentioned in Table 8, granular residues should meet the following additional criteria:

$$
\text { pH parameter --------------------------------- Limit value } \geq 6
$$

The lowest value registered in the analytical is 8.15 , higher than that indicated in the standard.

A simple observation of the comparative tables 8 and 9 give value to the performance of another species in leaching. The sulphate parameter decreases in the concrete samples with ferritic fume dust with respect to the amount of this same measure in conventional concrete.

\section{Conclusions}

The main findings throughout the work are listed below:

- Ferritic fume dust used as additive to concrete, gives a good workability, compactness and rigidity hardened material.

- Concrete mixtures with ferritic fume dust shown an improvement of their compressive strength in comparison with concrete mixtures with silica fume (both with the same proportion).

- The mechanical-resistant behavior of the concrete with the addition of ferritic fume dust powder achieves compressive and flexo-elastic resistances superior to conventional concrete.

- This material is classified as a special waste because it exceeds the limit of chromium, but this and other contaminants are stabilized in the cement matrix, as we have seen in the leaching of the concrete.

- It can be considered a micro-filler that can be used as a mineral addition in high or ultra-high performance concrete.

- A technique of stabilization/solidification of the ferritic fume dust with concrete was chosen, evaluating different proportions of this residue $5 \%, 10 \%$ and $15 \%$ of addition.

- First group not aged: Only the concentration values in leachate in chromium are somewhat higher than those of conventional concrete and very little above zinc and aluminum.

- Second group aged: Since in the total chrome it becomes less than in conventional concrete.

- The fact that in some elements such as total chromium that present slightly higher values in the second leaching, is motivated by the decrease in $\mathrm{pH}$ and the consequent partial dissolution of its hydroxides. 
Conflicts of Interest: The authors declare no conflict of interest.

Declaration statement: The data that support the findings of this study are available from the corresponding author upon reasonable request.

\section{Bibliography}

[1] Instituto Nacional de Estadistica. (Spanish Statistical Office), (n.d.). https://www.ine.es/ (accessed November 29, 2018).

[2] H.A. Colorado, E. Garcia, M.F. Buchely, White Ordinary Portland Cement blended with superfine steel dust with high zinc oxide contents, Constr. Build. Mater. 112 (2016) 816-824. doi:10.1016/j.conbuildmat.2016.02.201.

[3] M. Da, S. Magalhães, F. Faleschini, C. Pellegrino, K. Brunelli, Cementing efficiency of electric arc furnace dust in mortars, (2017). doi:10.1016/j.conbuildmat.2017.09.074.

[4] A.Herrero; M.A. Parrón, Proceso de obtención de metal a partir de los óxidos metálicos producidos durante la fabricación de aceros inoxidables, An. Ing. Mec. (2000).

[5] J. GMS Machado, F. Andrade Brehm, C. Alberto Mendes Moraes, C. Alberto dos Santos, A. Cezar Faria Vilela, J. Batista Marimon da Cunha, Chemical, physical, structural and morphological characterization of the electric arc furnace dust, J. Hazard. Mater. 136 (2006) 953-960. doi:10.1016/j.jhazmat.2006.01.044.

[6] F. Andrade Brehm, C. Alberto Mendes Moraes, R. Célia Espinosa Modolo, A. Cezar Faria Vilela, D. Carpena Coitinho Dal Molin, Oxide zinc addition in cement paste aiming electric arc furnace dust (EAFD) recycling, Constr. Build. Mater. 139 (2017) 172-182. doi:10.1016/j.conbuildmat.2017.02.026.

[7] C.F. Pereira, Y.L. Galiano, M.A. Rodríguez-Piñero, J.V. Parapar, Long and short-term performance of a stabilized/solidified electric arc furnace dust, J. Hazard. Mater. 148 (2007) 701-707. doi:10.1016/j.jhazmat.2007.03.034.

[8] C. Pellegrino, V. Gaddo, Mechanical and durability characteristics of concrete containing EAF slag as aggregate, Cem. Concr. Compos. 31 (2009) 663-671. doi:10.1016/j.cemconcomp.2009.05.006.

[9] M. Maslehuddin, F.R. Awan, M. Shameem, M. Ibrahim, M.R. Ali, Effect of electric arc furnace dust on the properties of OPC and blended cement concretes, (2011). doi:10.1016/j.conbuildmat.2010.06.024.

[10] G. Laforest, J. Duchesne, Stabilization of electric arc furnace dust by the use of cementitious materials: Ionic competition and long-term leachability, (2006). 
doi:10.1016/j.cemconres.2006.05.012.

[11] M. Parron-Rubio, F. Perez-García, A. Gonzalez-Herrera, M. Rubio-Cintas, M.E. ParronRubio, F. Perez-García, A. Gonzalez-Herrera, M.D. Rubio-Cintas, Concrete Properties Comparison When Substituting a 25\% Cement with Slag from Different Provenances, Materials (Basel). 11 (2018) 1029. doi:10.3390/ma11061029.

[12] M.D. Rubio-Cintas, F. Parrón-Vera, M.A, Contreras-Villar, Method for producing cinder concretee, n.d. ES20130000758 20130803. 3 June 2015.

[13] L. Coppola, A. Buoso, D. Coffetti, P. Kara, S. Lorenzi, Electric arc furnace granulated slag for sustainable concrete, Constr. Build. Mater. 123 (2016) 115-119. doi:10.1016/j.conbuildmat.2016.06.142.

[14] I. Arribas, A. Santamaría, E. Ruiz, V. Ortega-López, J.M. Manso, Electric arc furnace slag and its use in hydraulic concrete, (2015). doi:10.1016/j.conbuildmat.2015.05.003.

[15] F. Faleschini, M. Alejandro Fernández-Ruíz, M.A. Zanini, K. Brunelli, C. Pellegrino, E. Hernández-Montes, High performance concrete with electric arc furnace slag as aggregate: Mechanical and durability properties, Constr. Build. Mater. 101 (2015) 113-121. doi:10.1016/j.conbuildmat.2015.10.022.

[16] G. Salihoglu, V. Pinarli, N.K. Salihoglu, G. Karaca, Properties of steel foundry electric arc furnace dust solidified/stabilized with Portland cement, J. Environ. Manage. 85 (2007) 190197. doi:10.1016/j.jenvman.2006.09.004.

[17] D. De Domenico, F. Faleschini, C. Pellegrino, G. Ricciardi, Structural behavior of RC beams containing EAF slag as recycled aggregate: Numerical versus experimental results, Constr. Build. Mater. 171 (2018) 321-337. doi:10.1016/j.conbuildmat.2018.03.128.

[18] G. Adegoloye, A.-L. Beaucour, S. Ortola, A. Noumowe, Mineralogical composition of EAF slag and stabilised AOD slag aggregates and dimensional stability of slag aggregate concretes, (2016). doi:10.1016/j.conbuildmat.2016.04.036.

[19] N. Waijarean, S. Asavapisit, K. Sombatsompop, Strength and microstructure of water treatment residue-based geopolymers containing heavy metals, Constr. Build. Mater. 50 (2014) 486-491. doi:10.1016/j.conbuildmat.2013.08.047.

[20] A.-G. Guézennec, J.-C. Huber, F. Patisson, P. Sessiecq, J.-P. Birat, D. Ablitzer, Dust formation in Electric Arc Furnace: Birth of the particles, (2005). doi:10.1016/j.powtec.2005.05.006.

[21] M.S. Amin, S.M.A. El-Gamal, F.S. Hashem, Effect of addition of nano-magnetite on the hydration characteristics of hardened Portland cement and high slag cement pastes, J. Therm. Anal. Calorim. 112 (2013) 1253-1259. doi:10.1007/s10973-012-2663-1.

[22] Ky. Kirichenko, V. Drozd, V. Chaika, A. Gridasov, A. Kholodov, K. Golokhvast, Nano- and Microparticles in Welding Aerosol: Granulometric Analysis, Phys. Procedia. 86 (2017) 50-53. doi:10.1016/j.phpro.2017.01.017.

[23] X. Lin, Z. Peng, J. Yan, Z. Li, J.-Y. Hwang, Y. Zhang, G. Li, T. Jiang, Pyrometallurgical recycling of electric arc furnace dust, (2017). doi:10.1016/j.jclepro.2017.02.128.

[24] C.F. Pereira, M. Rodríguez-Piñero, J. Vale, Solidification/stabilization of electric arc furnace dust using coal fly ash Analysis of the stabilization process, 2001.

[25] C. Fernández Pereira, Y. Luna, X. Querol, D. Antenucci, J. Vale, Waste stabilization/solidification of an electric arc furnace dust using fly ash-based geopolymers, Fuel. 88 (2008) 1185-1193. doi:10.1016/j.fuel.2008.01.021.

[26] F. Montagnaro, L. Santoro, Reuse of coal combustion ashes as dyes and heavy metal adsorbents: Effect of sieving and demineralization on waste properties and adsorption capacity, Chem. Eng. J. 150 (2009) 174-180. doi:10.1016/j.cej.2008.12.022.

[27] C. Atiş, F. Özcan, A. Kılıc, O. Karahan, ... C.B.-B. and, undefined 2005, Influence of dry and wet curing conditions on compressive strength of silica fume concrete, Elsevier. (n.d.). 
644 [28] A.M. Neville, Properties of concrete, 4th and final edition. Harlow, Essex : Longman, 1995.

645 [29] P. Balfi , Influence of solid state properties on ferric chloride leaching of mechanically 646 activated galena, 1996.

[30] D. Xia, C. Pickles, Microwave caustic leaching of electric arc furnace dust, Miner. Engmeering. 13 (n.d.) 79-94.

[31] R. Duval, E.H. Kadri, Influencia of silica fume on the workability and the compressive strength of high-performance concretes, 1998.

[32] H. Toutanji, N. Delatte, S. Aggoun, R. Duval, A. Danson, Effect of supplementary cementitious materials on the compressive strength and durability of short-term cured concrete, (n.d.). doi:10.1016/j.cemconres.2003.08.017.

[33] Y. Reches, Nanoparticles as concrete additives: Review and perspectives, Constr. Build. Mater. 175 (2018) 483-495. doi:10.1016/j.conbuildmat.2018.04.214.

[34] P.E. Tsakiridis, P. Oustadakis, A. Katsiapi, S. Agatzini-Leonardou, Hydrometallurgical process for zinc recovery from electric arc furnace dust (EAFD). Part II: Downstream processing and zinc recovery by electrowinning, J. Hazard. Mater. 179 (2010) 8-14. doi:10.1016/j.jhazmat.2010.04.004.

[35] P. Xanthopoulos, S. Agatzini-Leonardou, P. Oustadakis, P.E. Tsakiridis, Zinc recovery from purified electric arc furnace dust leach liquors by chemical precipitation, J. Environ. Chem. Eng. 5 (2017) 3550-3559. doi:10.1016/j.jece.2017.07.023.

[36] S. Donatello, M. Tyrer, C.R. Cheeseman, Recent developments in macro-defect-free (MDF) cements, Constr. Build. Mater. 23 (2008) 1761-1767. doi:10.1016/j.conbuildmat.2008.09.001.

[37] Q. Wang, P. Yan, J. Yang, B. Zhang, Influence of steel slag on mechanical properties and durability of concrete, Constr. Build. Mater. 47 (2013) 1414-1420. doi:10.1016/j.conbuildmat.2013.06.044. 